\title{
Strengthening the Quality of Service Oriented to Medical Tourists: A Strategy for The Sustainability of The Hotel Sector in Barraquilla
}

\author{
María Isabel CASTELLANO ${ }^{1}$, Olga BITTAR $^{2}$ and Migdalia CARIDAD ${ }^{3}$ \\ 1,2Universidad del Norte, Barranquilla, Colombia \\ ${ }^{3}$ Institución Universitaria Tecnológico de Antioquia, Medellín, Colombia
}

Correspondence should be addressed to: María Isabel CASTELLANO; micastellano@uninorte.edu.co

Received date: 18 August 2020; Accepted date: 25 January 2021 ; Published date: 8 April 2021

Academic Editor: Martha Rodríguez-Villalobos

Copyright (C 2021. María Isabel CASTELLANO, Olga BITTAR and Migdalia CARIDAD. Distributed under Creative Commons Attribution 4.0 International CC-BY 4.0

\begin{abstract}
Medical tourism has shown a sustained increase in recent years in Colombia. As part of the DNA in the dynamics of the hotel sector, the quality of service is a fundamental aspect that determines how the medical tourist perceives his stay. Therefore, quality of service is the variable that directs this research, measured through five factors: Tangible Elements, Reliability, Responsiveness, Security and Empathy. In this sense, an objective was established to determine the strengthening of the quality of service oriented to the medical tourist as a strategy for the sustainability of the hotel sector in Barranquilla. Based on a survey of 215 subjects, the results showed that the quality of service received by the medical tourist is poor. Concluding that this behavior corresponds to the business model that owns the hotel sector in Barranquilla (oriented to the attention of business tourists) where no improvements have been made to give a differentiating value proposal aimed at providing attention towards the medical tourist, as a strategy for its sustainability in the market.
\end{abstract}

Keywords: Quality Of Service, Hospitality, Medical Tourism, Business.

\section{Introduction}

Since its genesis, tourism has brought significant changes in growth and variety, to the point that by 2028 , the travel and tourism industry is projected to be one of the most significant economic segments worldwide, expecting an increase of $11.7 \%$ in the global Gross Domestic Product (GDP), as set out by the president and CEO of the World Travel and Tourism Council (WTTC), Gloria Guevara Manzo at a media session in

Cite this Article as: María Isabel CASTELLANO, Olga BITTAR and Migdalia CARIDAD (2021)," Strengthening the Quality of Service Oriented to Medical Tourists: A Strategy for The Sustainability of The Hotel Sector in Barraquilla", IBIMA Business Review, Vol. 2021 (2021), Article ID 422393,

DOI: $10.5171 / 2021.422393$ 
Madrid (Noguera, 2019). In this sense, the prediction made by various international agencies and institutions estimates a worldwide sustained increase of tourist movements to reach 1.8 billion trips by 2030 (UNWTO, 2011).

Consequently, this is an activity that indisputably contributes to the economic development of the localities that adopt it as the primary axis of its commercial dynamics (Castro, Molina \& Pablo, 2013). In addition, it involves, in its service chain, a number of stakeholders that generate various sources of employment (Schenkel, 2019) of temporary or fixed order, which pays to the achievement of the Sustainable Development Goals (SDS), especially those aimed at promoting decent work opportunities as a significant boost for the inclusive growth (Ribeiro, 2017). Today, the needs of people have driven the emergence of other types of tourism, which, in turn, originated new business niches. An example of this is medical tourism which is highly sought after by a segment of the population increasingly interested in taking care of their health, opening up enormous possibilities for the elaboration of goods and services, using a distinctive technique paired with a synergistic process that aims at the construction of clusters between tourism and healthcare companies.

In this order of ideas, Fetscherin \& Stephano (2016) produced an index to determine the medical tourism destinations most demanded by the population worldwide, which they called the Medical Tourism Index (ITM). For their calculation, they were based on 4 dimensions: a) Country environment, where they evaluated elements such as cultural and linguistic similarities, economic stability and levels of corruption; b) Tourist destination, studying among its indicators, the attractiveness, popularity, exoticism and climatic conditions of the destination; (c) Costs of medical tourism, considering aspects such as affordability of air fares, travel costs, treatment costs and costs of the stay; and e) Facilities and services, evaluating the training, experience and reputation of physicians, quality standards in care and services, reputation for medical services, as well as recommendations from family and friends, among others. All this resulted in the Top 30 world's medical tourism destinations, which is led by Canada (76.9); followed by the United Kingdom (74.8) and the third place is for Israel (74.8), while Colombia (67.4) reached the eighteenth place, preceded in Latin America by Costa Rica (72.8) in the sixth place, Brazil (67.9) in the sixteenth place and Jamaica (67.7) in the seventeenth place (Sanchez-Vergara, 2017).

Faced with this panorama, it is interesting to note that research in the field of tourism focuses on regular tourism, whether associated with hotel service or more demanded destinations (Akbar, Wadood and Alzaidiyeen, 2010), while from the perspective of medical tourism, they emphasize the service provided by the health sector, (Heung, Kucukusta \& Song, 2011; Chuang, Liu \& Yachi, 2014, Lovelock \& Lovelock, 2018), and there are few that associate it with the hotel sector and medical tourism (Sadeh and Garkaz, 2018). That is why this research is aimed at determining the opportunities to strengthen the hotel sector through the quality of service it offers to the medical tourist.

To this end, different actors and stakeholders involved in both health and tourism fields were interviewed in order to have their perception on this subject. For the group of hotels, the instrument designed by the MinCit, called the Standard Assessment Guide was applied for the provision of the Health Tourism service, and for the group of health tourists or doctors, the instrument designed by Parasuraman, Zeithaml and Berry, 1991 called SERVQUAL, was selected because it has demonstrated its reliability and validity to measure the quality of service from the expectations and perceptions of its users.

The product achieved made it possible to determine that the business model of most of the hotels studied does not contemplate a value proposition aimed at meeting the demands of this growing segment of the tourist population, so the quality of the service perceived by customers does not generate the expected satisfaction. 


\section{Quality of service in the hotel sector}

Talking about the quality of tourist services, without taking into account the opinion of tourists would be inadmissible, since what is beyond the control of the company is impossible to measure, and without this evaluation process, it is unworkable to know the state of the company that leads it to undertake improvement strategies (Morillo, 2007).

That is why several authors have given their input to define the quality of services, some raise it as the extent to which a product or service responds to the requirements of the person who acquires or uses it (Montgomery, 2009). While for others, it is the gap between the expectations or desires of customers (expected service) and their perceptions (service received). Moreover, the quality of service is rated by the customer as the excellence of the service or product when comparing the expectations of the service to be obtained with the perception of the actions of the companies providing it (Parasuraman et al., 1991). From the position of Martin (1986), quoted in Ruiz, Vazquez and Díaz 1995, p.21)

Quality of service is a
combination of two
dimensions, that relating to
the procedure, which
depends on the technical
systems used to provide the
service and that related to
sociability, associated with
the supplier's ability to
relate to customers and
capture their needs.

This correlation between procedure and sociability contributes to the dilution of what is intended to be evaluated, to give a more consistent approximation of the quality of the service in the hotel sector in relation to where it should focus the improvements that contribute to raising that quality and thereby increasing customer satisfaction. Thus, several scholars have developed research aimed at assessing the quality of service from various aspects such as the study of Akbar,
Wadood and Alzaidiyeen (2010) in Malaysia in order to establish the relationship between the failures of the service presented by the hotel and factors such as perceived value, customer satisfaction and loyalty in the hotel industry. The results showed that perceived value and customer satisfaction are the two main variables for obtaining customer loyalty, mediating and redirecting the effect of the quality of service.

For their part, Kuei and Lu (2013) analyzed the need to implement quality policies in environments where demand is variable, as in the case of tourists, who now have multiple ways to obtain information on proposals that lead them to contract the service or product. These ways of accessing information are very different from those used years ago. Although this study is profiled towards marketing, it is a variable that was not considered in this research. This is significant because the expectations of the client are linked to the offer made by the accommodation provider.

Aznar, Bagur and Rocafort (2016) sought to relate the perception of the quality from hotel customers to the economic and financial results of hotels in order to determine whether the highest quality perception by users translates into better business results. It was found that they are not significantly related, which is consistent with other published research, where the bias in internet users' responses or the lack of internal motivations in the implementation of quality systems can be highlighted as possible causal agents.

Finally, Wu, Qomariyah, Sa \& Liao, (2018) set out to investigate the integration between service value and service recovery in the hotel industry by adopting a Quality Function Deployment (QFD) approach that integrates the Network Analytical Process (ANP) method into service. The results identified five groups of hotel service failures, which customers ranked more importantly as a) the room; b) arrival, check-in and check-out; c) restaurant, food and drink and d) facilities and other services. While on the service recovery side, 
the most effective means of dealing with failures were: "Immediate problem correction"; "Excuse me"; "Replacement"; "Discount".

Each of these studies, shows elements that must be interpreted by the hotel sector to make improvement decisions leading to the intervention of its business model, which leads to correcting the unsatisfying conditions found in its service, thus raising its quality. However, this requires involving, in any equation, the opinion of those who have received theoe services, allowing to know the level of satisfaction that each client has experienced when receiving the service, as expected, or as they offered it, and which may exceed their level of expectations. This optimal condition, (Sorensson and Friedrichs, 2013), is associated with the perception that travelers go to destinations where the satisfying quality of the services offered is fundamental. On the other hand, quality cannot be thought of as a unique concept (Zeithaml and Bitner, 2000), since it is necessary for hotels to respond to the aspirations and demands of tourism users that are increasingly changing (Izquierdo, Lazo and Andrade, 2018).

That is why, at present, the hotel sector cannot guarantee the efficiency of the business based solely on the conditions of accommodation infrastructure, since the tourist also demands to find a personalized treatment, friendly, accessible and pleasing to the eye. This reveals that the quality of the service is based on the perceptions that the client obtained about the services (Gadotti and França, 2009). This is consistent with what Monfort, Defante, de Oliveira and Mantovani (2013, p 279) said.

If the basic needs were not met, i.e. if the room was not clean, the employees were not helpful or there were communication failures, the facilities will not help. This is a dynamic set that must be worked on.

However, the focal point for any establishment is to determine, with the greatest possible objectivity, the quality of the service it provides; a fact that encompasses many dimensions, which implies increasing its level of complexity. For this reason, the dimensions and their measurement have generated instruments that allow the evaluation of the construct. In this sense, two scales, that have been representatives, stand out; one based on the model proposed by Parasuraman et al. (1985-1988-1991), and the other on the model proposed by Cronin and Taylor (1992).

Right now, it is proper to set position on how the quality of service is seen since the SERVQUAL Model, which is understood as a customer's opinion on the perceived service excellence (Parasuraman, Berry and Zeithaml 1991). This quality is measured by the scale of the same name, constituting 22 items distributed in five dimensions, since customers do not distinguish the quality of service as one-dimensional but discriminate a review of the service received (Zeithaml and Bitner, 2000).

The Parasuraman model is known as the SERVQUAL (Quality Service) model, which encompasses the study of customer expectations about the service to be received and perceptions about the service received, through five dimensions of the quality of service (in principle, there were 10 that were resized as a result of the reviews received) which they called tangibility, reliability, responsiveness, safety and empathy. For its part, Cronin and Taylor's model is called SERPERF (Service Performance) as its focus is on evaluating perceptions only, because it considers that the scale should focus on measuring the performance of the company or service provided, thus determining its effectiveness. (Cronin and Taylor, 1994).

However, it is noteworthy that both models are generated from the contributions of Grönross (1984), known as a Nordic model, based on two dimensions: the technical quality associated with the service that the customer receives and the functional quality associated with the way the customer receives the service. These dimensions, in turn, are mediated by the 
corporate image, which acts as a sieve of quality appreciation, i.e. the more positive this image is, the less significant the errors will be, and the customer will be more satisfied.

\section{Rise of Medical Tourism}

In order to investigate this issue, a relevant distinction can be made between health tourism and medical tourism, since the first constitutes the different intentions of people moving elsewhere to improve the conditions of their health (Ross, 2001), which involves not only the medical part but also that of welfare, as clear from the definition proposed by $\mathrm{Yu}$ and Ko (2012). While medical tourism implies traveling to destinations that involve technical competences associated with much more competitive prices by combining medical services with the tourism industry.

While for the Productive Transformation Program (PTP) (2013, p. 13), medical tourism is defined as "Travels with the primary objective of receiving curative, aesthetic or preventive treatments (illnesses, pains or surgical interventions)." According to the World Tourism Organization (UNWTO), medical tourism represents a tourist variety associated with the health sector, covering invasive or noninvasive treatments of an empirical nature, that is, it ranges from diagnosis to rehabilitation (OMT, 2018). For the purposes of this research, consideration shall be given to the definition proposed by $\mathrm{Yu}$ and Ko (2012) as it brings together the fundamental aspects for the medical tourist to choose a particular destination.

Globally, the rise of medical tourism is the product of substantive changes that have occurred to give attention to people who have health disorders or want to have some surgery abroad (Poveda and Gallegos, 2018), opening up opportunities that can be exploited by hotels, with a view of strengthening themselves in the market. This contribution from medical tourism would be permeated by a differentiating value proposition in its service offering. Therefore, medical tourism represents a tourist modality, in which various stakeholders are linked, giving it the character of transdisciplinarity whose involvement taxes substantive elements such as organization, development and execution, making any tourist destination include, in its offer packages, the services in which each interest group is an expert. (Martinez, 2016).

This global boom has guided the interest of medical tourists by marking preferences for some destinations in Africa and Asia such as: South Africa, Thailand, Mongolia, Hong Kong, Barbados, India and South Korea (Yang, Hu, Sun and Chen, 2018). While Latin America, the United States, Canada, Costa Rica, Brazil, Colombia and Jamaica (Sánchez-Vergara, 2017) stand out, taking into account some associated technology criteria, recognition of medical professionals, certification of health centers, as well as affordability in costs of procedures and treatments, among others.

However, this type of tourism continues to grow in Colombia, with cities such as Bogota, Medellin, Cali and Barranquilla preferred, as reflected in the study of Triviño, Ovalle and Díaz-Solano (2018), where they state that the city of Barranquilla is one of the objective poles for the progress of the Colombian Caribbean Coast due to its geographical position, so close to the touristic cities of Cartagena and Santa Marta. This helps Barranquilla become, touristically speaking, a competitive environment linked to the process of transformation, both urban and economic, that has evolved in recent decades. This progress is complemented by several factors such as good national and international connectivity, the various affordable medical treatment options offered by health centers and the varied hotel offers that make this city an attractive destination for medical tourists.

Among the studies carried out in the field of medical tourism, is the De la Puente's, 2015, which analyzes the dynamics of health tourism for the Colombian case, finding, as its main driver, the contribution of private actors from the use of competitive advantages associated with costs, facilities of access to the country and collaboration of 
national offices for the promotion of this type of tourism. On the other hand, there were some lacks found that limit the development of the market, highlighting the low level of bilingualism and the little communication between patients and doctors from the country of origin to the country of destination, generating cost oversteals to the international tourist.

Another significant study was the one developed by Yan et al., 2018, aimed at responding to one of the most important problems presented by tourists-patients in selecting an optimal destination to perform their medical procedures. To address this problem, they presented a new way of making group decisions with multiple criteria (MCGDM), allowing to evaluate and classify medical tourism destinations with vague information. The approach of diffuse Neutrosophic Preference Relationships (NFPR) resulted in tourists-patients who did not have information, time or patience to express their uncertainty about the assessment of their preferences.

Finally, the study developed by Triviño, et al. (2018) is presented to characterize and take medical tourism as a diagnosis for the formation of a cluster. Out of a total of 390 centers, the results characterize the capacity and quality of the three accredited health centers in the city of Barranquilla which are enabled to provide this service. In addition, they detected the level of individualism in the culture of the business fabric of the sector and the lacks in the management of a second language as a substantive element for the medical tourism service. As a result, they raise the need to incorporate a significant number of accredited companies into the health sector, as well as to adopt a region tourism vision that facilitates the linkage of complementary tourism services.

This study opens up the possibility of incorporating the hotel sector as a complementary player in the provision of services according to the requirements, needs and conditions of the medical tourist, who has limited possibilities to find accommodation that provides him with a space of comfort and specific services of good quality to be able to complete his recovery phase. As could be seen, most studies deal with medical tourism and the hotelier separately, a gap that aims to be reduced by this research. However, both form a binomial that opens up multiple business opportunities to respond to this segment, which would make it possible to contribute even more to the region's economy. Several transnationals have been incorporated into the hotel sector, giving vivacity to this important sector, thus demonstrating that the city has the capacity to hold considerable volumes of tourists including those who come for health care reasons.

Over the past decade, in the health sector in Barranquilla, the modernization of structures, technological updating and the creation of new institutions have been made way for, strengthening the supply of services. It has been a significant change that has driven economic development in various sectors - related or not related - to health institutions, the hotel and gastronomic sector (Triviño, et al. 2018, p.144).

In this sense, it should be noted that Barranquilla registered an increase of 3.4\% during 2017, represented by a number of 113,809 tourists compared to 72,519 during 2016. (Migration Colombia, 2017, p. 22). However, there are many studies aimed at evaluating, determining and analyzing the quality of the service provided to the tourism sector, but they all conver conventional tourists, which is obviously the largest segment of the sector. Neverthless, in recent years, medical tourism has entered firmly into the spectrum of the market, requiring differentiating elements when accessing accommodation, search that is regularly not successful.

In view of this scenario, it is necessary for the hotel industry to know the needs of medical tourists in terms of infrastructure, human resources, food requirements and so on, providing them with a service that 
leaves them satisfied, since many of these tourists require accommodation appropriate to their condition, that is, with certain requirements that collaborate in their recovery in a harmonious and integral way. In addition, it is necessary to consider that this type of tourist never travels alone, usually accompanied by a family member or a close friend who also requires a high comfort service that helps him manage the load of the physical and mental stress generated by taking care of a patient, to efficiently fulfill his role as an escort.

While the hotel sector is not a health institution, the medical tourist is also not a conventional tourist, so his patient status is present, and his needs and requirements focus on developing an adequate rehabilitation process. In this sense, the accommodation provider must be aware that the service provided to this type of tourists must be special, trying to articulate synergistically with the health centers from which these tourists come, in order to provide a quality service. (PTP, 2013). However, it is noteworthy that the hotel sector in Barranquilla has its focus on business tourism, indicating that there is no differentiating aspect towards the segment of the medical tourist who selects it as a touristic destination for its treatments or health procedures.

\section{Methodology}

The study has a quantitative approach, determined as descriptive, because the variables were analyzed individually, in the light of theories and data, to strengthen the quality of service oriented to medical tourists as a strategy for the sustainability of the hotel sector in Barranquilla. According to its timeline, it was cross-cutting with the non-experimental design because the data was collected without any modification. The procedure for collecting information was performed in the field. The research thread was distributed in 3 phases, the first based on the revision of different databases both physical and electronic to provide theoretical support to the study.
Consequently, books, complete scientific articles, both in English and Spanish, reports of congresses and conferences, as well as reports of agencies and institutions, were considered among others.

In the second phase, an instrument called the Indicative Standards Guide for the provision of Health Tourism services by the Hotel Sector (PTP, n.d.) was applied to hotel managers who agreed to be part of the population under study (15 in total). It should be mentioned that this phase took place during the months of March-April 2018. In the third phase, the SERVQUAL scale (Parasuraman, et al., 1991) was applied to tourists through their treating physicians for data confidentiality reasons. A total of 300 instruments were delivered. This phase took place during the months of July-November 2018. It should be noted that only 200 duly diligence instruments were returned, forming the entirety to be analysed.

\section{Indicative Guide to Standards for the Provision of Health Tourism Services by the Hotel Sector}

This guide is a tool proposed by the TP, which allows hotel establishments to identify their way of participating in the health tourism services. As clear from this specification, the guide is exploratory in nature, as it tells hotel managers about those areas that require improvements in order to serve medical tourists. The instrument included 7 dimensions, grouped into 93 items, addressing human talent ( 6 items), infrastructure (24 items), health tourist care (30 items), communication with medical tourists (4 items), measurement, analysis and improvement (5 items) and finally sustainability (18 items). The alternatives were designed under the Likert scale which were from 0 to 5 . The data was organized by dimension in an Excel sheet and exported to the SPSS program for descriptive calculation, expressed in frequencies and percentages. For its assessment, a scale of criteria was developed. 
Table 1: Criteria Scale

\begin{tabular}{|c|c|}
\hline Range & Criteria \\
\hline $\mathbf{0 - 1 9}$ & No Standard \\
\hline $\mathbf{2 0 - 3 9}$ & Scarce Standard \\
\hline $\mathbf{4 0 - 5 9}$ & Under Standard \\
\hline $\mathbf{6 0 - 7 9}$ & Medium Standard \\
\hline $\mathbf{8 0 - 9 9}$ & High Standard \\
\hline $\mathbf{1 0 0}$ & Excellent Standard \\
\hline
\end{tabular}

Source: self-crafting, 2018

\section{SERVQUAL Model (Quality Service)}

With this instrument, the quality of the hotel service given to the medical tourist was measured, some simple adaptations were made aimed at contextualizing approaches to the hotel sector. To use this instrument, an authorization from Dr. Parasuraman, one of the authors of the SERVQUAL scale, was obtained. It consists of five dimensions that measure the quality of the service offered from two ways, the first measures the expectations customers (medical tourists) have about the conditions they expect to find during their stay in the hotel, and the second measures the perceptions of those same customers about the service received during their stay. The dimensions correspond to: tangible elements (furniture, equipment and installations, personal appearance and food); reliability, associated with the way the hotel provides the service to customers, prevailing a careful and reliable service; and responsiveness, encompassing the care and assistance that the hotel provides for its customers in a timely manner and without dilation, managing the willingness to collaborate with them.

The security dimension, measures the knowledge, skills and respectoffered to the client. Finally, the empathy dimension measures the connection with the client by interpreting and understanding his situation, needs and conflicts, all in order to pay himpersonalized attention. This questionnaire uses the semantic differential scale (Osgood, Suci and Tannenbaum, 1957) from 1 to 7 , where 1 represents, on the scale of expectations, the criterion of very insignificant, and 7 represents very important. While, in perceptions, 1 represents the criterion of totally dissatisfied and 7 totally satisfied. As can be noted, both expectations and perceptions were estimated by the degree of importance that subjects attach to each of the 22 statements or items in the questionnaire.

Scale values that measure the quality of service expected and received by customers are obtained by calculating the difference between the averages obtained by each of the 22 items, both expectations and perceptions, in the five dimensions. While to determine the value of the definitive gap that the opinion yields on the quality of service received, the average value of perception is subtracted from the average value of expectation (P-E), if this is positive $(\mathrm{P}>\mathrm{E})$ then the perception exceeded the expectation of the customer, considering a high level of quality received. Otherwise, if the values are negative $(\mathrm{P}<\mathrm{E})$, it would be in the presence of a perceived low level of quality. However, if there is equality between the two ( $\mathrm{P} \mathrm{s} \mathrm{E}$ ), it would be in the presence of a modest level of quality of the service received.

\section{Results by Discussion}

The data from the instrument called the Indicative Guide to Standards for the Provision of Health Tourism Services by the Hotel Sector are reflected in Table 2, with the percentages of statistical frequencies yielded for the seven factors assessed, which shows that the factors with the highest standard were communication with medical tourists, and the measurement, 
analysis and improvement of standards to provide a health service, both with $100 \%$ each, corresponding to the excellent standard, followed by sustainability with $89.87 \%$, and addressing with $85.3 \%$, all in the high standard criterion, according to the scale, which represents a great strength. However, when comparing the overall percentages of frequencies (73.94), with the scale designed, they are at the medium standard criterion, a situation that could be affected by the values achieved, in human talent (29.31\%) infrastructure accommodation (35.55\%), placing them at the low standard criterion.

These results are consistent with what Triviño, et al. (2018) propose, where one of their conclusions demonstrated the lacks in Human Talent in the management of a second language as a substantive element for the medical tourism service. This coincides with the opinion of De La Puente (2015), where there were lacks that limit the development of the market, highlighting the low level of bilingualism, little communication between patients and doctors from the country of origin to the country of destination, generating lack of care for the international tourist.
As seen from these results, the human talent of the hotel sector studied shows that it does not live up to the responsibilities involved in the care of a tourist-patient. Many of these customers come from English-speaking countries, which requires the check-in/out or customer service staff to master a second language. It is also necessary that all staff members who are in contact with the clients, must be trained for the care of health tourism services users, including first aid training, identification of alarm signals, basic cardiopulmonary resuscitation (CPR) or first responder course.

In correspondence with the above, the hotel industry requires identifying the needs of this segment of the tourist population and giving adequate attention to the infrastructure, human resources, food.. etc. to provide this type of service and leave its visitors satisfied. (Portafolio, 2014). This confirms the fact that customers do not distinguish the quality of a service from one-dimensionality, but discriminate against the information to reach an assessment of the service received (Zeithaml and Bitner, 2000)

Table 2: Results of the Indicative Guide to Standards for the Provision of Health Tourism Services by the Hotel Sector

\begin{tabular}{|l|l|l|l|l|c|c|}
\hline \multicolumn{1}{|c|}{ Factors } & Excellent & High & Medium & Low & Very low & Null \\
\hline Direccionamiento & 85,3 & 0,0 & 14,7 & 0,0 & 0,0 & 0,0 \\
\hline Human talent & 29,31 & 13,7 & 54,48 & 2,5 & 0,0 & 0,0 \\
\hline Infrastructure & 35,55 & 20,34 & 43,62 & 0,0 & 0,0 & 0,0 \\
\hline Attention to the tourist & 77,5 & 8,43 & 13,92 & 0,0 & 0,0 & 0,0 \\
\hline Communication & 100 & 0,0 & 0,0 & 0,0 & 0,0 & 0,0 \\
\hline $\begin{array}{l}\text { Measurement, analysis } \\
\text { and improvement }\end{array}$ & 100 & 0,0 & 0,0 & 0,0 & 0,0 & 0,0 \\
\hline Sustainability & 89,87 & 0,33 & 9,8 & 0,0 & 0,0 & 0,0 \\
\hline T0TAL\% & $\mathbf{7 3 , 9 3}$ & 6,11 & 19,5 & 0,36 & 0,0 & 0,0 \\
\hline
\end{tabular}

Source: self-crafting based on data, 2018

As for the overall results of the SERVQUAL scale, which address the gaps between expectations and perceptions denoted by the medical tourists surveyed, are presented in Table 3, where it is clear that all dimensions involve negative values, which shows that the expectations of medical tourists were not exceeded by the accommodation provider, interpretating, through data, a low level of quality of the service received, that is, the customer was not satisfied. 
Continuing with the analysis, the results show that the greatest distance is located in the dimension "tangible elements" with an amplitude of -0.637 , which represents the lowest perceived level of quality, which showed that medical tourists, in general, were not satisfied with the appearance of the accommodation, the modernity of the equipment, the food received, nor the appearance of the staff who attended them. It is likely that the appearance of the hotels has not been a determining factor, since most of them have modern facilities, however, the fact that they do not have rooms that are minimally equipped for the care of the medical tourists, as well as the specialized food service, may have affected their perception.

In this sense, it is confirmed that hotel guests are concerned with the quality of the facilities, that is why some accommodation providers confuse the level of the facilities with the quality of the service. However, if the basic needs were not met (for example if the room was not clean, the employees were not helpful, the service was late.. etc), the facilities will not help. "This is a dynamic set that needs to be worked on." (Monfort et al., 2013, p. 279).

Similarly, the security dimension was worth $-0,542$, which denotes that the service associated with a conduct of respect, tranquility, confidence and privacy in customer service, were not sufficiently covered by the hotel, which resulted in a low level of satisfaction for the medical tourist. While most hotels have a safe deposit box to safeguard customers' belongings, the medical tourist requires other mechanisms that allow him to protect the medical supplies necessary for his recovery treatment during his departures, this is further strengthened when the staff members, who are in direct and indirect contact with the client, do not preserve confidentiality.

Here, the role that management plays as the main head is to give the required importance to the needs and requirements of health tourists, because the quality is based on the perceptions that the client has about the services received (Gadotti and França, 2009). Thus, perceived value and customer satisfaction are the two main variables to obtain customer loyalty, mediating and redirecting the effect of the quality of service (Akbar et al., 2010).

As seen from the results, the hotel sector is not providing medical tourists with a different service than what it usually offers to the rest of the tourists, which corroborates what is expressed by Monfort et al. (2013) that quality goes beyond a good accommodation. Since the quality of the service is systemic and integral,it will only be enough that some of the expectations are not met, which will make accommodation not well valued, as evidenced in table 3 of results.

Table 3: Integral Gap. Quality of service provided to medical tourists Expectations Perceptions

\begin{tabular}{|c|c|c|c|c|c|}
\hline & Mean(e) & $\begin{array}{c}\text { Standard } \\
\text { Deviation }\end{array}$ & Mean(p) & $\begin{array}{c}\text { Standard } \\
\text { Deviation }\end{array}$ & Gap \\
\hline $\begin{array}{c}\text { Tangible } \\
\text { Elements }\end{array}$ & 6,500 & 0,000 & 5,863 & 0,252 & $\mathbf{- 0 , 6 3 7}$ \\
\hline Reliability & 6,280 & 0,274 & 5,790 & 0,220 & $-0,490$ \\
\hline Responsiveness & 6,600 & 0,250 & 6,075 & 0,264 & $-0,525$ \\
\hline Security & 6,280 & 0,214 & 5,738 & 0,263 & $\mathbf{- 0 , 5 4 2}$ \\
\hline Empathy & 6,380 & 0,274 & 5,910 & 0,174 & $-0,47$ \\
\hline
\end{tabular}

Source: self-processing based on data (2018) 


\section{Conclusions and Recommendations}

Colombia, and in particular Barranquilla, continues to position itself on the radar of many health touristic destinations. There are many characteristics that make it a tempting destination in this field, the ease of connection, the advanced technology in the various disciplines, the proven and internationally recognized quality of its doctors and health centers, the world-class hotel plant, the competitiveness in the costs of surgical procedures and treatments of less complexity.. etc.

However, some aspects have been highlighted that limit the use of opportunities arising from medical tourism: (a) The absence of a differentiating service offering aimed at capturing the medical tourism segment; b) A homogeneous service provided to the medical tourist that does not differ from the care provided to the conventional tourist; c) Little information and training of human talent to care for a medical tourist; d) Lacks in demonstrating skills such as multilingualism or, if not, English language proficiency, human relations, assertive communication and technical capabilities to engage with a tourist-patient.

Therefore, it would be advisable to suggest that the hotel sector initiates a review of its business model in order to initiate an improvement process that incorporates a differentiating value offer, based on the specific knowledge of its needs, requirements and uncertainty, aimed at capturing the care and interest of the medical tourist to select it as an appropriate accommodation during his recovery.

Similarly, the hotel sector would strengthen its competitiveness in the market by making itself visible in the spectrum of health tourism and linking its service chain to other stakeholders such as travel agencies, private nursing, transport, medical supplies (pharmacies, micro-enterprises of medical equipment.. etc.) which, in turn, would make it part of the group of companies that are not only intended to gain profit but to contribute to achieving some of the Objectives of the Sustainable Development, because linking other minority stakeholders would advocate for decent work opportunities that minimize poverty rates in the region.

\section{References}

- Akbar, S, Som, APM, Wadood, F and Alzaidiyeen, NJ, (2010). "Revitalization of service quality to gain customer satisfaction and loyalty",International Journal of Business and Management, [online] [Consulted 18-03-2018]. Available:

https://pdfs.semanticscholar.org/034 b/fbc313159391c88521547b1eb4897 9328e94.pdf.

- Aznar, JP, Bagur, Ll, Rocafort, A, (2016)“Impact of service quality on competitiveness and profitability: The hotel industry in the Catalan coas.Intangible Capital, [online]. [Consulted 23-03-2018]

- Available:http://www.intangiblecapita l.org/index.php/ic/article/view/693. DOI:http://dx.doi.org/10.3926/ic.693

- Castro, M., Molina, JA, y PabloRomero, MP. (2013). 'Turismo y PIB.UN meta análisis de estudios de datos de panel'. Journal of Travel Research, 52 (6), 745 - 758.

- Cronin, J. y Taylor, S. (1992). "Measuring Service Quality: A Reexamination and Extension".Journal of Marketing, [online]. [Consulted 2303 -

2018].Availablehttps://www.jstor.org /stable/pdf/1252296.pdf?refreqid=ex celsior\%3A5ff84a6212d6e214151190 40678a9338.

- Cronin, J. y Taylor, S. (1994). "Servperf vs. Servqual: reconciling performancebased and perceptions-minusexpectations measurement of service quality".Journal of Marketing. [online]. [Consulted 18-03-2018]. Available: https://www.academia.edu/3252696/ SERVPERF versus SERVQUAL_reconcil ing performancebased and perceptions-minus- 
expectations measurement of service quality.

- Chuang, TC, Liu, JS, Lee, Y, Lu LYY, (2014)."The main paths of medical tourism: From transplantation to beautification".Tourism Management. [online]. [Consulted 23-032018].Available:

- $\quad$ https://doi.org/10.1016/j.tourman.20 14.03.016. (http://www.sciencedirect.c om/science/article/pii/S0261517714 $\underline{000727)}$

- De la Puente, M. (2015)."Health Tourism Sector: Case of Colombia". Caribbean economy. [online]. [Consulted 18-03-2018].Available: https://dialnet.unirioja.es/servlet/arti culo?codigo $=6143212$

- Fetscherin M. and Stephano, R.M. (2016). "The medical tourism index: Scale development and validation".Tourism Management. [online] [Consulted 17-03-2018] Available:

- https://scholarship.rollins.edu/cgi/vie wcontent.cgi?article $=1238 \&$ context $=$ as facpub

- Gadotti, S. y França, A. (2009)."The measurement of the quality of service: an application in hotel companies".European Journal of Business Management and Economics. [online].[Consulted 17-032018]Available: https://dialnet.unirioja.es/ejemplar/2 $\underline{13920}$

- Grönroos, Ch. (1984). “A Service Quality Model and its Marketing Implications".European Journal of Marketing. [online]. [Consulted 18-032018]Available:

https://www.researchgate.net/publica tion/233522386_A_Service_Quality_M odel_and_Its_Marketing_Implications/d ownload. [Consultado 18-04-2018]

- Heung, V, Kucukusta, D, Song, H. (2011). "Medical tourism development in Hong Kong: An assessment of the barriers". Tourism

Management.
[online].[Consulted23-03-

2018].Available:https://www.academi a.edu/6175341/Medical tourism deve lopment in Hong Kong An assessmen $\mathrm{t}$ of the barriers

- Izquierdo Vera, R. M., Lazo Serrano, C. A., \& Andrade Ríos, M. A. (2018)."The hotel quality through the Servqual scale in hotels in the province of El Oro, Ecuador". University and Society.[online]. [Consulted 23-042018].Available: http://rus.ucf.edu.cu/index.php/rus.

- $\quad$ Kuei, C.H.; Lu, M.H. (2013). "Integrating quality management principles into sustainability management".Total Quality Management \& Business Excellence. [online]. [Consulted 23-042018]

- Available:http://dx.doi.org/10.1080/1 $\underline{4783363.2012 .669536}$

- Lovelock, B, Lovelock. K. (2018) “We had a ball ... as long as you kept taking your painkillers" just how much tourism is there in medical tourism? Experiences of the patient tourist. Tourism Management. [online]. [Consulted 24-03-2018]. Available:http://www.sciencedirect.co $\mathrm{m} /$ science/article/pii/S02615177183 $\underline{01080}$

- Martínez, D. (2016). "Medical Tourism: Generalities for your comprehensive understanding". Tourism and Society. [online]. [Consulted 25-032018].Available: DOI: http://dx.doi.org/10.18601/0107555. $\underline{\mathrm{N} 19.08 .}$

- Migración Colombia (2017). Annual Statistics Bulletin January-December 2017.[online]. [Consulted 18-032018].Available:http://migracioncolo mbia.gov.co/phocadownload/Bolet\%C 3\%ADn\%20Flujos\%20Migratorios $\% 2$ 02017\%20(003).pdf.

- Monfort, M., Defante, L., Oliveira, D. y Mantovani, D. (2013)."The staff were very good and the staff were very nice. Strategic implications".Tourism Studies 
and Perspectives. [online]. [Consulted 22-03-2018]

- Avalaible:

http://www.redalyc.org/articulo.oa?id $=180726078005$.

- Montgomery, DC. (2009). "Introduction to statistical Quality Control".6 $6^{\text {th }}$ edn. John Wiley \& Sons. [online]. [Consulted 23-04-2018] Avalaible: https://endustri.eskisehir.edu.tr/ipoyr az/TKY302/icerik/text\%20book_mont gomery_6th\%20edition.pdf

- Morillo, M. (2007)."Analysis of the quality of hotel service through the SERVQUAL Scale".Visión gerencial. [online]. [Consulted 23-042018]Available:http://www.saber.ula. ve/bitstream/handle/123456789/251 52/articulo8.pdf?sequence $=2$ \&isAllow ed $=y$

- Noguera, N. (2019)."World Tourism Council projects growth of $3.8 \%$ by 2028". Viajar Diario eltiempo. Com, 22 de enero 2019.[online].[Consulted 3101-2019] Available: https://www.eltiempo.com/vida/viaja r/retos-del-consejo-mundial-de-viajesy-turismo-wttc-para-el-2028-317492

- United Nations World Tourism Organization (OMT).Tourism by 2030. Global overview. Madrid: OMT (2011).

- World Tourism Organization. (2018). "Exploring Health Tourism. Executive Summary". UNWTO.[en línea]. Madrid, [Consulted 31-01-2019].Available: DOI: https://doi.org/10.18111/978928442 $\underline{030.8}$

- $\quad$ Osgood, C.E., Suci, G., y Tannenbaum, P. (1957). "The measurement of meaning".Psicothema. [online]. [Consulted 23-04-2018]. Available: https://www.press.uillinois.edu/book s/catalog/32mtm7sx9780252745393. $\underline{\text { html. }}$

- $\quad$ Parasuraman, A., Berry, L.\& Zeithaml, V. (1991) "Refinement and reassessment of the SERVQUAL Scale". Journal of Retailing. [online]. [Consulted 23-04-
2018].Available:

https://www.researchgate.net/publica tion/247373898_Refinement and reas sessment of the SERVQUAL instrume $\underline{\mathrm{nt}}$

- Parasuraman, A., Zeithaml, V., \& Berry, L. (1988). "SERVQUAL: a multiple-item scale for measuring consumer perceptions of service quality". Journal of Retailing. [online]. [Consulted 18-032018]

- Available: https://search.proquest.com/docview L228609374?pq-origsite=gscholar

- Parasuraman, A., Zeithaml, V., \& Berry, L. (1985). "A Conceptual Model of Service Quality and its Implications for Future Research".Journal of Marketing. [online]. [Consulted 23-04-2018] Available:https://www.jstor.org/stabl e/1251430?origin=ISTOR$\% 20$ df\&seq=1\#metadata info tab co ntents.

- Portafolio. (2014). "Health tourism seeks to grow more in Colombia".Portafolio, 08 de abril. [online]. [Consulted 18-03-2018]. Available:https://www.portafolio.co/e conomia/finanzas/turismo-saludbusca-crecer-colombia-66184.

- Poveda, G. y Gallegos, M. (2018). "Dental medical tourism in Ecuador as a new exportable offer of non-traditional services for the promotion and development of the national economy".Observatory Journal of Latin American Economics. [online].[Consulted 23-11-18]. Available https://www.eumed.net/rev/oel/inde x.html.

- Programa de Transformación Productiva (2013). Business plan for the wellness tourism subsector in Colombia.[online]. [Consulted 19-042018].Available: https://www.ptp.com.co/CMSPages/G etFile.aspx?guid=80fca027-7c4e-458588f7-a349ed5a1a0b. 
- Programa de Transformación Productiva (n.d.).Manual of basic standards of hotel organizations that offer services in health tourism programs.[online]. [Consulted19-042018].Available:

https://www.ptp.com.co/ptp-

servicios/ptp-

herramientas/documentos/manual-

de-estandares-basicos-de-

organizaciones-hot.aspx

- Ribeiro, J., (2017).Definition of indicators of the implementation of the SDGs in the Americas: ILO contributions. [online]. [Consulted 1904-2018].Available:https://www.ituccsi.org/IMG/pdf/jose_ribeiro indicado res ods.pdf

- Ross, K. (2001). "Health tourism: an overview". HSMAI Marketing Review. [online].[Consulted 23-042018].Available:http://www.hospitalit ynet.org/news/4010521.search.

- $\quad$ Ruiz, A.; Vázquez, R.; Díaz, A. (1995). "The perceived quality of service in rural tourism hotel establishments". Papers de Turisme. [online].[Consulted 18-04-2018]

- Available:http://www.papersdeturism e.gva.es/ojs/index.php/Papers/article /view/304

- Sadeh, E. \& Garkaz, M. (2018). "Interpretative structural modeling of quality factors in both medical and hospitality services in the medical tourism industry".Journal of Travel \& Tourism Marketing. [online]. [Consulted 19-04-

2018].Available:https://doi.org/10.10 $\underline{80 / 10548408.2018 .1527273}$

- Sánchez-Vergara S. (2017)."Trends, profiles and motivation of health and wellness tourism". The Ostelea. School of Tourism \& Hospitality. [online]. [Consulted 19-032018].Available:http://www.aept.org/ archivos/documentos/informe turism o de salud y bienestar ostelea.pdf

- Schenkel, A. (09-05-2019). “Top social tourism experiences in Latin America".Alba Sud.[en línea].
[Consultado 31-01-2019]. Disponible: http://www.albasud.org/blog/es/110 8/principales-experiencias-deturismo-social-en-latinoam-rica

- $\quad$ Sorensson, A. Von Friedrichs, Y . (2013). "An importance-performance analysis of sustainable tourism: A comparison between international and national tourists".Journal: of destination Marketing and Managament. [online]. [Consulted 23-042018].Available:https://www.research gate.net/publication/257744923_An_I mportance-

Performance Analysis of Sustainable Tourism A Comparison Between Inter national and National Tourist

- Triviño, D., Ovalle, D., Díaz-Solano, B. (2018)."Medical tourism in the city of Barranquilla: context analysis for the creation of a cluster".Caribbean Economics Magazine. [online]. [Consulted 20-072018].Available:http://www.scielo.org .co/pdf/ecoca/n21/2011-2106-ecoca21-131.pdf.

- Wu, WY., Qomariyah, A., Sa, NTT \&Liao, YK.(2018). "The Integration between Service Value and Service Recovery in the Hospitality Industry; An Application of QFD and ANP".International Journal of Hospitality Management. [online]. [Consulted 31-012019].Available:https://doi.org/10.10 16/j.ijhm.2018.03.010.; http://www.sciencedirect.com/scienc e/article/pii/S0278431917310666

- Yang, Y. Hu, J.; Sun, R. and Chen, X. (2018). "Medical tourism destinations prioritization using group decision making method with neutrosophic fuzzy preference relations".Scientia Iranica E. [online]. [Consulted 31-012019].

Available:http://scientiairanica.sharif. edu/article 4514 b8ba518c066810f00 b2dcb08fbcba49a.pdf

- Yu., \& Ko, T. G. (2012). “A cross-cultural study of perceptions of medical tourism among Chinese, Japanese and Korean 
tourists in Korea".Tourism Management. [online]. [Consulted 2304-2018].

Available:https://doi.org/10.1016/j.to urman.2011.02.002.

http://www.sciencedirect.com/scienc e/article/pii/S026151771100046X.
- Zeithaml, V.A. y Bitner, M.J. (2000). Services marketing: Integrating customer focus across the firm. $2^{\mathrm{a}}$ Ed. Boston: McGraw-Hill 